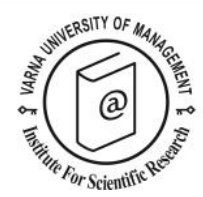

\title{
Exploring the images of hospitality line-level employment: Hotel employees' perceptions vs. the general public's perceptions
}

\author{
Galia Fuchs ${ }^{1 *}$ Arie Reichel ${ }^{2}$ and Yaniv Poria ${ }^{3}$
}

\begin{abstract}
${ }^{1}$ Ben-Gurion University of the Negev, Department of Hotel and Tourism Management, Guilford Glazer Faculty of Management, Beersheba, 84105, Israel. E-mail: galiaf@som.bgu.ac.il

${ }^{2}$ Ben-Gurion University of the Negev, Department of Hotel and Tourism Management, Guilford Glazer Faculty of Management, Beersheba, 84105, Israel. E-mail: arier@som.bgu.ac.il

3 Ben-Gurion University of the Negev, Department of Hotel and Tourism Management, Guilford Glazer Faculty of Management, Beersheba, 84105, Israel. E-mail: yporia@som.bgu.ac.il

* Corresponding author
\end{abstract}

\begin{abstract}
The study explores, compares, and contrasts the image of line-level hotel employment and its underlying dimensions as held by the general public and by hotel employees. Additionally, this study clarifies the images of six specific line-level occupations. A quantitative research approach was adopted. The analysis included 302 hospitality employees and 273 participants representing the general public. The findings revealed that the image of line-level employment is a multifaceted concept, represented by eight factors that were further utilized for the identification of the employment image profiles of the combined two samples. Furthermore, the study found differences in images of six line-level occupations, indicating higher rankings provided by current hospitality employees. Managerial implications and suggestions for future research are presented.
\end{abstract}

Keywords: Employment image; dimensions; line-level employees; hospitality employment

Citation: Fuchs, G., Reichel, A. \& Poria, Y. (2021). Exploring the images of hospitality line-level employment: Hotel employees' perceptions vs. the general public's perceptions. European Journal of Tourism Research 27, 2703 


\section{Introduction}

The literature on hospitality management is abundant with findings concerning the image of line-level hotel employment and its demanding working conditions. Many studies have compared working conditions, behaviour, and image of hotel blue-collar employees or, line-level employees and those of their supervisors or managers (e.g. Shamima, Cang, \& Yu, 2017). Among line-level employees we find housekeeping staff, waiters, receptionists, and security personnel. The images related to their working conditions include wages, work environment, round-the-clock work hours, emotional exhaustion, lack of camaraderie at the "back of the house," as well as the challenging nature of some employees' behaviour (Baum, 2002; Cheng \& Tung, 2019; Karatepe \& Karatepe ,2009; Koc \& Bozkurt, 2017; Pearlman \& Schaffer, 2013; Pizam, 1982; Walmsley, 2004; Wood, 1997). Globalization and the European Union's inter- and intra-continent migration laws, have further eroded the image of line-level hotel employment (Joppe, 2012; Zopiatis, Constanti \& Theocharous, 2014), with employees from less developed nations seeking employment in an industry with a problematic image (Janta, Brown, Lugosi, \& Ladkin, 2011; Janta, Ladkin, Brown, \& Lugosi, 2011). In developed nations, this change in employee makeup has brought about local residents' reluctance to join the hospitality workforce (Joppe, 2012).

Singh, $\mathrm{Hu}$, and Roehl (2007) claimed that it is important to capture how the industry's career is perceived by external (potential) employees as well as by the internal workforce. The aversion felt toward employment in the hospitality industry, and especially toward some of the occupations in it, can be attributed to their social image as low-class occupations. The important role of society's reference group was highlighted by Goh and Lee (2018) who found that families of Generation Z hospitality workforce had a strong influence on their career choice. In broader sociological perspectives, notable studies by Pfeffer (1977) and Baron (1984), indicated that work organizations are important generators of social stratification. Hence, the image of employment in the hospitality industry could be a significant indicator of social stratification, and as such, this image has a considerable impact on recruitment and sustainability of human resources in hospitality organizations.

In line with the above, this study was designed to clarify the image of line-level hospitality employment perceived by the public, and go one step further by comparing hotel employees' and the general population's perceptions. Indeed, relatively few systematic empirical studies focused on the image of line-level employment by comparing the hotel industry with the general public. Therefore, in this empirical study, we not only explore line-level employment image but also raise the question of whether this image is compatible with that held by the public within a specific region or nation.

Baum (2018) claimed that workforce and employment issues in tourism cannot be interpreted without reference to the wider social, cultural, and economic context, and in Israel, where this study was conducted the societal context includes the powerful role of the hi-tech industry (Senor \& Singer, 2011). The hi-tech industry is a significant economic sector, whose influence exceeds the sector's size or number of its employees (Rosenberg, 2018; Shachmurove, 2019).

Alongside the socially and economically prestigious hi-tech sector, there is an influx of migrant workers into Israel, many of whom find their way into line-level occupations in the hospitality industry (Krakover, 200o; Population and Immigration Authority, 2018). While no solid statistics are available, mass media convey the message that these illegal migrant workers find shelter in menial occupations such as in hotels, reinforcing the negative image of hotel line-level employment. Clearly, a problematic industry employment image, held either by line-level hotel employees or the public, may portray a precarious situation to the industry, mainly in terms of human-resource management. Vicariously, this imbalance might be detrimental to academic and professional hospitality management programs. In 
addition to the industry employment image, we attempted to explore the images of various line-level hospitality jobs, and see whether there are different patterns of appreciation and evaluation between the public and hospitality employees. If the images are not compatible, this could be a critical factor in recruitment efforts.

To fill the gap in the literature this study has three objectives.

- $\quad$ First, to explore the image of line-level employment and its underlying dimensions as held by the general public and hotel employees;

- $\quad$ Second, to compare and contrast the image dimensions held by line-level hotel employees vs. those held by the general public;

Third, to clarify the images of six specific line-level occupations held by the general public vs. the hotel line-level employees.

\section{Literature Review}

The image of employment in an industry affects the willingness of potential candidates to seek a job in that industry (Vigoda \& Ben-Zion, 2003), and a positive industry or job image motivates employees to perform better (e.g. Baum, 1995; Browne \& Golembiewski, 1974). According to Reichel, Fuchs, Pizam, and Poria (2014) and Shani, Uriely, Reichel, and Ginsburg (2014) the accumulated literature on employment in the hospitality industry indicates almost exclusively that line-level hotel jobs have a negative image that has long been observed and documented. For example, in 1982, Pizam characterized the work environment for unskilled and semi-skilled employees in the hospitality industry as physically unpleasant with an outdated managerial system, employees' feelings of subservience, a high proportion of foreign and minority employees, limited career progression, inconvenient work hours and low wages. A study by Reichel and Pizam (1984) compared the U.S. hospitality industry employees' work attributes, demographics and lifestyles with employees in four other industry groupings. They found that hospitality employees represent minority groups and large families, perceiving themselves to be of lower social class, in comparison to employees in other sectors. Hospitality employees were less satisfied with their job and life in general, and did not consider their job to be an important element for their selfaccomplishment. Baum (1995) highlighted the role of low wages as a key determinant in formulating the problematic employment image of hospitality line-level employees. Similarly, Wood (1997) and Walmsley (2004) noted hospitality industry line-level employment as associated with low social status and wages, often belonging to disenfranchised segments of society, subjected to poor supervision, temporary and seasonal jobs with a high proportion of foreign job-seekers, lacking specific career paths and few, if any, work challenges.

An in-depth review of the literature on hotel line-level employment conditions indicates consistent findings since the 1980, all of which explain the negative image of hospitality employment. These include long, unsociable hours and unfavourable pay and conditions (Lindsay \& McQuaid, 2004; Reichel et al., 2014; Rowley et al., 2000), inconvenient work hours, sexual discrimination and narrow job functions (Choi, Woods, \& Murrmann, 2000), low-skilled work and lack of training opportunities (Szivas, 1999). Moreover, the negative aspects of line-level employment for women have been particularly noted (De Kadt, 1984; Faulkenberry, Coggeshall, Backman, \& Backman, 200o; Momsen, 1994; Pattullo, 1996).

Indeed, images of low status and social marginality in hotel employment seem to be associated with unsavoury, deviant behaviours, including occupational violence, substance abuse, and petty crime by fellow employees (Connolly, 2000). In addition, Robinson (2008) depicted a disconcerting image of the hotel employees as prone to deviant behaviour and abuse by the guests. In this respect, sexual 
provocation and harassment of hotel employees by guests is apparent (Gurrierr \& Adib, 20oo; Yagil, 2008). Similar results were reported in a review by Ram (2018), portraying the industry as inflicted with violence, bullying and sexual harassment.

In addition, the hospitality industry has been affected by a growing migration of peoples from less developed nations into developed nations (Filimonau \& Mika, 2012; French, 2018). In 2010 an International Labour Organization (2010) report referred to the impact of employment of "marginal groups" on the industry. Joppe's (2012) study on the hospitality sector in OECD countries illustrates a major shift toward employing migrant workers. For example, Zopiatis et al. (2014) described the Cypriot hotel work force as being $58 \%$ migrant. While some of whom speak practically no Greek, they are nonetheless invaluable to the Cypriot economy due to the diminishing interest of the locals in hospitality professions and careers. Similarly, Hsieh Apostolopoulos, Hatzudis and Sönmez (2014) noted the poor working conditions of Latina hotel cleaners in USA hotels, which render them particularly vulnerable to elevated occupational hazards that could lead to adverse health outcomes. Clearly, these trends could have a negative impact on line-level employment image.

In a collective volume on international hospitality human resource management, Hoffman, Johnson, and Lefever (2000) depicted alarming issues in hospitality employment across numerous nations toward the 2000, describing the macro, global, and societal views of the employment image of the hospitality industry from the public's viewpoint. For example, Kattara (2000) described high turnover, harsh working conditions, and low wages in the Egyptian hospitality industry. France is characterized by an immense social and educational gap among the various employee hierarchies (Boullé \& Reithler, 200o). In Korea, Patton (2000) reported a very high turnover due to irregular working hours, low wages, hard physical work, and low prestige associated with hospitality-industry employment. In Greece (Skoulas, 200o), the poor image of employment in the hospitality industry is associated with seasonal work that does not allow for career advancement. Connolly (2000) attributed the negative image of employment in the Irish hospitality industry to hoteliers' avoidance of paying overtime, and abuse of under-age employees. It is interesting to note that Lebanon's dominant image of hospitality employment emanates from social attitudes toward hospitality: "people associate the hospitality industry with nightlife, gambling, low wages, limited career opportunities and moral or behavioural corruption” (Ladki, 20oo, p. 175).

It should be noted, however, that line-level status is not necessarily synonymous with low wages (Zopiatis et al., 2014). Some line-level employees, particularly those covered by labour union contracts or collective bargaining agreements, earn competitive wages. Additionally, line-level employees in many nations are not exempt from the fair labour standards acts, which means they are entitled to overtime compensation. According to Baum (1995), most studies ignore the gratuities as well as other unofficial benefits that line-level employees receive (i.e. tips or gifts).

Most twentieth-century studies emphasize the negative employment image of the hospitality industry. While the first two decades of the twenty-first century have yielded very few studies on hospitality industry image, it may be possible to detect some changes. Indeed, the issues of hospitality employment image and its dimensions call for an in-depth and systematic investigation in more recent days. Additionally, the possible gap between the public perceptions and employee's perception is enlightening both in term of the sociology of hospitality enclaves with unique occupational values vs. society, and subsequently the firms' ability to attract and retain employees.

This study also attempts to explore whether there is a culture of stratification within the hospitality enclave, so that different jobs are associated with different ranks of prestige. Finally, we raise the macro- 
question of line-level employment images of the hospitality industry against the backdrop of two socioeconomic conflicting forces: a hi-tech industry that is financially rewarding and offers employees prestige vs. a wave of underclass low-paid illegal migrant workers. The impact of the latter group was detected in a preceding qualitative study (Reichel et al., 2014) that indicated the presence of illegal migrant workers in Israeli hotels negatively affects the self-perception of the rank-and-file occupations.

\section{Methodology}

\section{Instrument}

Given the nature of the research objectives, a quantitative research approach was adopted. Accordingly, a questionnaire was designed in two versions: one for hotel employees, and the other one for those not working in the hospitality industry. The two versions were almost identical except for a set of questions related to current employment in the hospitality industry.

The questionnaire was comprised of five sections, four of which are of relevance to this paper. Dutton and Dukerich's (1991) holistic contextualization of image as encompassing all actions and achievements in the work environment was adopted. To measure the variety of dimensions of line-level employment image we selected components based on previous studies (Baum, 1996, 2002; Baum, Amoah, \& Spivack, 1997; Riley, 1996). In addition, an initial exploratory in-depth qualitative study was conducted to extract image perceptions (Reichel et al., 2014). This part of the study involved 4o people, among whom were hotel employees, retired hotel employees, and people without any hotel-industry experience. The perceptions gleaned related to working conditions, occupational profiles, job characteristics and requirements, and moderating factors such as the reputation of the hotel.

The set of 30 items, rated on a 5-point Likert scale (1 - I do not agree, 5 - I agree) reflects the image of line-level hotel employment (See: Table 1 for variables included in the analysis). Another set of questions concerned the image (1-negative vs. 5-positive) of six line-level jobs (waiter, cook, maintenance crew, room attendant, receptionist, and security guard). These jobs were selected based on the literature as well as on an interview with the Head of Human Resource Management for Israel Hotel Association (Bahar, 2017), and constitute the majority (90\%) of hotel line-level jobs. The questionnaire concluded with a section focusing on participants' socio-demographic items and questions related to their previous and current work experience.

\section{Data Collection}

Data from hotel employees was collected during January 2013 in several locations in Israel to ensure a wide range of respondents for external validity. The data was at the disposal of the Israel Hotel Association and released for scientific analysis and publication at the end of 2017. No major developments have taken place since then that might have proven this data obsolete. For example, migrant employees were still a major issue in August 2018 (Cohen, 2018), and it seemed that the employment patterns reported here are here to stay. The questionnaires were quasi-randomly distributed (systematic sampling) to hotel employees by trained research students. Specifically, the trained research students were instructed to attempt toward maximal random sampling, by visiting different hotels at different hours. Hotel locations included the resort city of Eilat (Royal Beach, Harrod's Palace, Astral) as well as in Jerusalem (Inbal, King Salomon, Mamila), Tel Aviv (Dan, Sheraton, Hilton), Beer Sheba (Leonardo), Haifa (Dan Carmel, Crown Plaza), and at the Dead Sea (David, Leonardo, Lot). These were all four- to five-star-equivalent hotels. The project's personnel had access to all hotel employees from all departments, and freely distributed the questionnaires on the employees' organized transportation to/from work, in their accommodation quarters, and in employees' dining rooms. Access was facilitated by the Israel Hotel Association due to their interest in the study's findings. 
Most of the questionnaires were distributed in Jerusalem and in Tel Aviv hotels (84 and 81 respectively). Dead Sea accounted for 58 questionnaires, Haifa for 48, and Beer Sheba -30 .

The general public's data $(N=273)$ was collected in January 2013 in quasi-random sampling approach in the cities of Tel Aviv ( $n=44)$, Haifa (41), Eilat (32), Beer Sheba (28), Dead Sea Area (25), Herzlia (30), Natanya (33) and Jerusalem (40). We considered these cities as representing a wide range of Israeli citizens. Respondents were approached with paper questionnaires in central bus stations, pedestrian malls, and beaches. The average response rate of the two samples was $89 \%$. Each questionnaire took on average 15 minutes to complete. The authors believe that the relatively open communication culture prevalent in Israel enabled the research students to feel at ease approaching people, asking for cooperation. All respondents in this study filled out the paper questionnaires in the presence of the research students. In a few cases the questionnaire was read to the interviewee. The questionnaire included a screening question to ensure that respondents of the public sample are not employed in the hospitality sector.

\section{The Sample Characteristics}

A total sample of 575 persons aged 18 and above were divided into 302 current hotel line-level employees and 273 participants representing the general public. Table 1 depicts the sample characteristics

Table 1. The Sample Characteristics $(N=575)$

\begin{tabular}{llll}
\hline & Hospitality employees & The public & Total \\
\hline $\begin{array}{l}\text { Gender } \\
\text { Female }\end{array}$ & $172(58.9 \%)$ & $120(41.1 \%)$ & $292(50.9 \%)$ \\
\hline Age group & $129(45.7 \%)$ & $153(54.3 \%)$ & $282(49.1 \%)$ \\
$18-21$ & & & \\
$22-30$ & $44(48.4 \%)$ & $47(51.6 \%)$ & $91(15.8 \%)$ \\
$31-40$ & $150(52.6 \%)$ & $135(47.4 \%)$ & $285(49.6 \%)$ \\
$41-50$ & $53(68.8 \%)$ & $24(31.2 \%)$ & $77(13.4 \%)$ \\
$51-60$ & $32(56.1 \%)$ & $25(43.9 \%)$ & $57(9.9 \%)$ \\
$61-67$ & $21(42.0 \%)$ & $29(58.0 \%)$ & $50(8.6 \%)$ \\
$68+$ & $2(15.4 \%)$ & $11(84.6 \%)$ & $13(2.2 \%)$ \\
\hline Perceived annual income & $2(100 \%)$ & $32(5.6 \%)$ \\
Below average & $205(53.4 \%)$ & & $384(66.8 \%)$ \\
Average & $70(60.3 \%)$ & $179(46.6 \%)$ & $116(20.2 \%)$ \\
Above average & $27(36.0 \%)$ & $46(39.7 \%)$ & $75(13.0 \%)$ \\
\hline Total & $302(52.5 \%)$ & $48(64.0 \%)$ & $575(100 \%)$ \\
\hline
\end{tabular}

It should be noted that the mode age category is 22-30. This by default reflected the age distribution of hospitality employees in Israel who tend to join the industry after their compulsory military service at the age of 22 (Bahar, 2017). This distribution of the hotel line-level employees is in line with the current income distribution in the hospitality sector in Israel (Bahar, 2017). In both research groups, the distribution of age, gender, and income is similar, with no statistically significant differences found.

\section{Results}

In line with the research objectives, the results section comprises of three sections. First, the overall sample image dimensions of line-level employment are presented, and the underlying factors are identified. Next, a Discriminant Analysis was conducted to demonstrate different profiles of employment images between the line-level hospitality employees and the public sub-samples. 
Following that, comparisons of the employment images of specific six line-level jobs are conducted between the line-level hotel employees and the public sub-samples.

The Image of Line-Level Employment in the Hospitality Industry

Principal Component Analysis (PCA) was conducted to extract factors, or latent dimensions with Varimax rotation. Aggregating all respondents resulted in a relatively large sample that facilitated the calculation of solid factors that capture the variance of the range of employment images. As seen in Table 2, the analysis yielded eight factors, including 22 variables explaining 59.3\% of the variance; $\mathrm{KMO}=$ o.68; Bartlett's Test (Chi-Square= 2380.74; $d f=231$; Sig=0.0o) (see Iacobucci \& Churchill, 2010). All factor Eigenvalues are greater than 1.

As seen in Table 2, Factor 1 focuses on job (dis)advantages such as pride in work, future job opportunities, the glittering image of the job, and job security (tenure); Factor 2, hospitality is (not) for everyone, is related to the age of employees and perceived inability to find jobs elsewhere. Interestingly, being a native-born employee seems to be a liability. The third factor refers to the lack of need for knowledge, professional training and academic education; the fourth factor, "Required sacrifices", includes sacrificing family life, work-family conflict, and low wages. Similarly, the fifth factor includes working on weekends and over holidays. The sixth factor entails (poor) service environment in the sense that service-providers image is low, ex-soldiers do not know how to provide good service, while some guests exhibit unruly behaviour toward female employees. Factor 7, "Sense of entitlement", comprised of two locally oriented dimensions: Israeli guests' sense of entitlement and discharged soldiers working for the sole motivation of their anticipated six-month "preferred industry" bonus check. Finally, the eighth factor relates to migrant employees' suitability for the hospitality industry.

The examination of these eight factors reveals that the image of line-level employment is a multifaceted concept. It comprises, among other elements, of issues ranging from work environment perceptions to employee characteristics, as well as to guest behaviour, all of which are important to the conceptualization of hospitality line-level employment image. Note however that the reliability of some of the factors as measured by Cronbach's Alpha are relatively modest.

\section{A Comparison between Hotel Employee's Perceptions and the General Public's}

To clarify the differences in the perceptions of the line-level hospitality employment image factors between current employees and the general population, a Two-Group Discriminant Analysis (DA) was employed. Utilizing the eight constructed image factors yielded the DA model presented in Table 3.

Attempting to examine group "membership" according to the sign of the centroids indicates that hotel line-level employees are associated with the following hospitality employment image factors: (no) need for knowledge, required sacrifices, (non) standard work hours, and sense of entitlement. On the other hand, the public sample is associated with the three following hospitality employment image factors: job (dis)advantages, hospitality is (not) for everyone, and (poor) service environment. The findings clearly indicate that each group exhibit a distinct, identifiable profile. 
Table 2. Principal Component Analysis of the image of line-level employment in the hospitality industry $(N=575)$

\begin{tabular}{|c|c|c|c|c|}
\hline Factor & Loading & Eigenvalues & $\begin{array}{l}\text { Percentage } \\
\text { of variance } \\
\text { explained }\end{array}$ & $\begin{array}{l}\text { Cronbach's } \\
\text { Alpha }\end{array}$ \\
\hline Factor 1 - “Job (dis)advantages" & & 2.91 & 12.12 & 0.730 \\
\hline Employees in hotels are like a family* & 0.74 & & & \\
\hline Hospitality employees are proud of their work* & 0.70 & & & \\
\hline $\begin{array}{l}\text { Hospitality jobs open opportunities in other } \\
\text { industries* }\end{array}$ & 0.67 & & & \\
\hline Working in hotel has a glittering image ${ }^{*}$ & 0.64 & & & \\
\hline Employees in hotels have job security (tenure)* & 0.57 & & & \\
\hline Factor 2 - "Hospitality is (not) for everyone" & & 1.94 & 8.07 & 0.620 \\
\hline $\begin{array}{l}\text { The hospitality industry is suitable for only } \\
\text { young employees }\end{array}$ & 0.75 & & & \\
\hline $\begin{array}{l}\text { Veteran hotel employees probably could not } \\
\text { find a job elsewhere }\end{array}$ & 0.72 & & & \\
\hline $\begin{array}{l}\text { Working in the hospitality industry is not } \\
\text { suitable for native-born employees }\end{array}$ & 0.70 & & & \\
\hline Factor 3 - “(No) need for knowledge” & & 1.86 & 7.74 & 0.560 \\
\hline $\begin{array}{l}\text { This work requires high-level professional } \\
\text { training* }\end{array}$ & 0.75 & & & \\
\hline $\begin{array}{l}\text { You don't need to study anything in particular } \\
\text { to work in a hotel }\end{array}$ & 0.65 & & & \\
\hline $\begin{array}{l}\text { Working in the hospitality industry requires an } \\
\text { academic degree* }^{*}\end{array}$ & 0.63 & & & \\
\hline Factor 4 - "Required sacrifices" & & 1.75 & $7 \cdot 31$ & 0.530 \\
\hline $\begin{array}{l}\text { Working in a hotel requires sacrificing your } \\
\text { family life }\end{array}$ & 0.75 & & & \\
\hline $\begin{array}{l}\text { Working in hospitality is not suitable for } \\
\text { employees with families }\end{array}$ & 0.66 & & & \\
\hline Wages in the hospitality industry are low & 0.51 & & & \\
\hline Factor 5 - “(Non)standard work hours” & & 1.70 & 7.07 & 0.89 \\
\hline You are expected to work also on weekends & 0.92 & & & \\
\hline Employees are required to work on holidays & 0.92 & & & \\
\hline Factor 6 - “(Poor) service environment" & & 1.53 & 6.36 & 0.480 \\
\hline Service personnel has a negative image & 0.75 & & & \\
\hline $\begin{array}{l}\text { Discharged soldiers do not know how to provide } \\
\text { good service in hotels }\end{array}$ & 0.73 & & & \\
\hline $\begin{array}{l}\text { There are guests who make a pass at female } \\
\text { employees }\end{array}$ & 0.50 & & & \\
\hline Factor 7 - "Sense of entitlement" & & 1.40 & 5.81 & 0.370 \\
\hline $\begin{array}{l}\text { Domestic guests believe they are entitled to } \\
\text { everything }\end{array}$ & 0.73 & & & \\
\hline $\begin{array}{l}\text { Discharged soldiers work in hospitality because } \\
\text { they receive government incentives }\end{array}$ & 0.65 & & & \\
\hline Factor 8 - "Migrant employees" & & 1.16 & 4.84 & \\
\hline $\begin{array}{l}\text { Working in the hospitality industry is suitable } \\
\text { for migrant workers }\end{array}$ & 0.77 & & & \\
\hline
\end{tabular}


Table 3. Discriminant Analysis of the public vs. current employee's employment image dimensions

\begin{tabular}{ll}
\hline Image factors & Standardized Coefficients \\
\hline "Job (dis)advantages" & 0.76 \\
"Hospitality is (not) for everyone" & 0.18 \\
"(No) need for knowledge" & -0.13 \\
"Required sacrifices" & -0.46 \\
"(Non)standard work hours" & -0.30 \\
"(Poor) service environment" & 0.33 \\
"Sense of entitlement" & -0.30 \\
"Migrant employees" & 0.05 \\
\hline & Functions at Group Centroids \\
\hline Current employees $n=302$ & Centroids -.382 \\
The public $n=273$ & Centroids .391 \\
Wilks' Lambda $=.87$, Chi-square $=76.12, d f=8$, & \\
Sig.= .ooo & \\
$66.2 \%$ of the cases correctly classified & \\
\hline
\end{tabular}

\section{Line-Level Occupations Image Evaluations}

As noted earlier, this study also investigates the images of specific six line-level hotel occupations. As can be seen in Table 4, there are significant differences in three comparisons between six occupations. Measured on a 5-point scale, the image perceptions varied from 5 - a very positive image, to 1 - low image. The paired-sample $t$ tests indicate four ranks of jobs image: (1) receptionists (4.08), (2) security guards (3.78) and cooks (3.7), (3) waiters (3.32) and maintenance crew (3.25), and (4) Room attendants (2.8).

Table 4. Six Line-Level Occupation Image Perceptions - Paired Samples t-test (total sample)

\begin{tabular}{lllllll}
\hline Line-level occupations & $\boldsymbol{N}$ & Mean & $\begin{array}{l}\text { Std. } \\
\text { Deviation }\end{array}$ & $\boldsymbol{t}$ & $\boldsymbol{d f}$ & $\begin{array}{l}\text { Sig. (2- } \\
\text { tailed) }\end{array}$ \\
\hline Receptionists & 573 & 4.08 & .94 & 6.37 & 576 & 0.00 \\
Security guards & 574 & 3.78 & $\mathbf{1 . 1 2}$ & & & \\
\hline Security guards & 574 & 3.78 & 1.12 & 1.54 & 577 & 0.12 \\
Cooks & 575 & 3.70 & 1.12 & & & \\
\hline Cooks & 575 & 3.70 & 1.12 & 8.02 & 577 & 0.00 \\
Waiters & 575 & 3.32 & 1.14 & & & \\
\hline Waiters & 575 & 3.32 & 1.14 & 1.16 & 577 & 0.25 \\
Maintenance crews & 575 & 3.25 & 1.50 & & & \\
\hline Maintenance crews & 575 & 3.25 & 1.50 & 7.12 & 576 & 0.00 \\
Room attendants & 573 & 2.80 & 1.32 & & & \\
\hline
\end{tabular}

Additionally, a comparison was made between the two sub samples (hotel employees vs. the general public) on the image of the specific six line-level occupations. As seen in Table 5, there are four statistically significant differences between employees' perceptions of the image of different occupations vs. the public's perceptions, with line-level hotel employees assigning higher occupational images. No statistically significant differences were found between the two sub-samples relating to waiters and cooks. In both sub-samples, images of receptionists were the highest. The two samples converge on the lowest image assigned to room attendants. 
Table 5. Differences in images of six line-level jobs: The public vs. hospitality employees t-tests

\begin{tabular}{|c|c|c|c|c|c|c|c|}
\hline Job & $\begin{array}{l}\text { Sub- } \\
\text { samples }\end{array}$ & $N$ & $\begin{array}{l}\text { Image } \\
\text { Mean }\end{array}$ & $\begin{array}{l}\text { Std. } \\
\text { Deviation }\end{array}$ & $t$ & $d f$ & $\begin{array}{l}\text { Sig. (2- } \\
\text { tailed) }\end{array}$ \\
\hline \multirow[t]{2}{*}{ Receptionists } & $\begin{array}{l}\text { hospitality } \\
\text { employees }\end{array}$ & 300 & 4.16 & 0.97 & 2.30 & 570.96 & 0.02 \\
\hline & the public & 273 & 3.98 & 0.89 & & & \\
\hline \multirow[t]{2}{*}{ Security guards } & $\begin{array}{l}\text { hospitality } \\
\text { employees }\end{array}$ & 301 & 3.90 & 1.17 & 2.64 & 572 & 0.01 \\
\hline & the public & 273 & 3.65 & 1.07 & & & \\
\hline \multirow[t]{2}{*}{ Cooks } & $\begin{array}{l}\text { hospitality } \\
\text { employees }\end{array}$ & 302 & 3.64 & 1.17 & -1.20 & 573 & 0.23 \\
\hline & the public & 273 & 3.75 & 1.07 & & & \\
\hline \multirow[t]{2}{*}{ Waiters } & $\begin{array}{l}\text { hospitality } \\
\text { employees }\end{array}$ & 302 & 3.34 & 1.22 & 0.39 & 570.36 & 0.69 \\
\hline & the public & 273 & 3.30 & 1.03 & & & \\
\hline \multirow[t]{2}{*}{ Maintenance crews } & $\begin{array}{l}\text { hospitality } \\
\text { employees }\end{array}$ & 302 & 3.35 & 1.25 & 1.72 & 573 & 0.05 \\
\hline & the public & 273 & 3.14 & 1.73 & & & \\
\hline \multirow[t]{2}{*}{ Room attendants } & $\begin{array}{l}\text { hospitality } \\
\text { employees }\end{array}$ & 300 & 2.93 & 1.41 & 2.67 & $567 \cdot 36$ & 0.01 \\
\hline & the public & 273 & 2.64 & 1.18 & & & \\
\hline
\end{tabular}

A closer examination of Table 4 indicates that there are different patterns of ranking between the two groups. Specifically, the general public's ranking ranges from receptionists (highest) to cooks, security guards, waiters, maintenance crews, ending with room attendants (lowest). The line-level hotel employee rankings are somewhat different. The highest ranked job is receptionist, followed by security guards, cooks, maintenance crews, waiters, ending with room attendants. These findings are of significance to industry recruitment efforts, as will be discussed later.

\section{Discussion}

In sum, employment image is a crucial component in human resource management, and although linelevel employees are essential to hotel operations, surprisingly no empirical studies have yet clarified in details the quantitative dimensions of hotel-industry line-level employment image. Moreover, no studies compared the public's image of hotel line-level employment with that of the line-level hotel employees themselves. In line with the above, this study represents an attempt to minimize the current gap in the literature. Moreover, the study was conducted in Israel, under conditions of a hospitality industry whose image could be at risk given the burgeoning hi-tech industry, and at the same time, absorbing the contested segment of illegal employment seekers. The former can negatively impact the image of employment in hospitality in terms of salary, skills and education required. At the same time the hospitality sector image is further eroded due to absorbing the weak, less skilled and illegal migrant menial job seekers.

The findings indicate that hotel line-level employment image is a multifaceted construct composed of eight different factors. Moreover, it was found that hotel line-level employee's image is associated with the following profile: (no) need for knowledge, required sacrifices, (non)standard work hours, and sense of entitlement. On the other hand, the general public's image profile consists of job (dis)advantages, hospitality is (not) for everyone, and (poor) service environment. In addition, the findings indicate that different line-level occupations have different images, and that there is a clear hierarchy between these occupations. The findings clearly indicate that receptionists, for example, have a much better image than room attendants. Also, it was revealed that line-level hotel employees have a different perception 
of occupational hierarchy than the general public. In line with the above, the practice of grouping together all line level occupations as "blue colour" or "rank and file" requires new consideration as each is perceived differently.

As noted earlier, to better understand the underlying dimensions of the overall image of line-level employment of both employees and the general public, eight factors were extracted. Most are congruent with the body of literature in tourism and hospitality management. For example, non-standard work hours and substantial sacrifice required are well documented as elements affecting the hotel work image (Baum, 2007; Brown, Thomas, \& Bosselman, 2015; Pearlman \& Schaffer, 2013; Pizam, 1982). Also, the factor of "(no) need for knowledge" included an explicit item asserting that employment in the hotel industry does not require professional training. This claim was noted in numerous studies (e.g. Szivas, Riley, \& Airey, 2003: Pizam \& Shani, 2009).

Unsettling issue is related to the finding about sexual provocations by guests toward female employees (Factor Six). Such patterns of guest behaviour are well documented (Gilbert, Guerrier, \& Guy, 1998; Guerrier \& Adib, 2000; Kensbock, Bailey, Jennings, \& Patiar, 2015; Yagil, 2008) and at times erroneously contributed to a prejudicial image of hospitality industry employees as "morally questionable" (Ladki, 2000). This finding is also congruent with a more recent study by Reichel et al. (2014) who found that in leisure resorts in Israel there was a tendency among male guests to verbally harass female employees. Somehow, possibly a redeeming process, the current study also revealed the spontaneous development of a "family-like" atmosphere among line-level employees (Factor One). Based on Shani et al. (2014), this family-like atmosphere may help create an accepting atmosphere for the smooth handling of emotional labour. As will be outlined later, it can serve as a basis for developing a core of skilled, loyal cadre of employees.

The dimension of "job (dis)advantages" relates to negative aspects of line-level employment, such as lack of pride and comradery. This illustrates that old-fashioned images as reflected long ago in Pizam's study (1982) still dominate the image of employment in the hotel industry, rather than the more modern, liberal approach that emphasizes employee rights, appreciation, and respect by hotel guests (Pizam, 2003; Pizam \& Shani, 2009).

As noted above, the image of line-level hospitality employment includes also the factor of "hospitality is (not) for everyone". This factor is comprised of the perception that line-level employment befits mainly young employees who did not find a better job, those who cannot find jobs elsewhere, and nonnatives. The first two components are akin to the previously reported descriptions of the hotel industry work environment by Wood (1997) and Walmsley (2004), while the latter echoes Zopiatis et al. (2014) account. Clearly, the public's image of hotel industry line-level employment emerges here as suited for those who cannot find jobs elsewhere (Baum, 1995).

As noted above, the Discriminant Analysis (DA) indicated that hotel line-level employees' image is associated with four out of the eight image factors extracted, including: "required sacrifices," "(non)standard work hours," "a sense of entitlement," and "(no) need for knowledge." One can argue that these factors are especially familiar and relevant to those who gained experience in the hotel industry. The findings concerning "required sacrifices” and “(non)standard work hours", including long working hours and work on holidays and weekends are again, congruent with Baum et al. (1997), Wood (1997), Rowley et al. (2000), Lindsay and McQuaid (2004) and Walmsley (2004). The fourth factor "(no) need for knowledge" - has prevailed worldwide since the early 1980s (Baum, 2002, Pizam, 1982; Szivas et al., 2003). 
The third employees' image factor, "a sense of entitlement" indicates a clear country-particular image dimension, comprising of two specific items: "domestic guests believe they are entitled to everything" and "discharged soldiers work in hospitality only because it is considered a preferred industry." These two variables are noteworthy in the Israeli context as they indicate a certain degree of reservation of fellow employees and criticism on domestic (i.e., Israeli) guests. It is possible to consider the image of discharged soldiers as disdain for their future options beyond the hospitality employment. "Staying behind" in line-level jobs might be considered a bleak scenario, given sociologists Pfeffer (1977) and Baron's (1984) argument that one's social stratum is highly dependent on progress prospects. The findings are in line with a previous study by Reichel and Amit (2000) who found that contrary to hoteliers' expectations, the discharged soldier status contributes to the deteriorating image of employment in the Israeli hotel industry.

It is interesting to note that according to the findings here the issue of migrant workers is of little significance - it did not play a major role in the Discriminant Analysis results and made only a marginal limited contribution to the factor analysis. This surprising finding is especially notable in relation to studies on Polish migrant workers in the hospitality sector in United Kingdom (Brown, et al. 2011; Ladkin, et al. 2011) and East European hospitality employees in Cyprus (Zopiatis, et al. 2014). The current study assumption stipulated that the flow of illegal migrant workers who found refuge in the hospitality business might have negative notable consequences in terms of the image of employment in the hospitality industry, was rejected.

As for identifying the image of various line-level occupations, our findings indicate four ranks of images (1 - receptionists, 2 - security guards and cooks, 3 - waiters and maintenance crews, 4 - room attendants). Receptionists' highest rank emanates possibility due to their intensive interactions with guests. Clearly, this image also corresponds with the expertise required for the job. Security personnel have a lower, but still relatively positive image. This may be because people often feel security threats in Israel and therefore assign high importance to the role of security guards. Cooks hold the same image rank as security guards, perhaps due to the ever-growing prestige of chefs in popular culture in Israel (Ganem, 2017). Next ranked are the waiters and maintenance crews. It can be speculated that both are ranked low given the perception that they require limited skills. Finally, room attendants have the lowest image, possibly because this is considered a job without any skill requirement. Also, based on Reichel et al. (2014), serving as room attendance is a common outlet for migrants and illegal immigrants in Israel. Given the above discussion of the hierarchy of images, it is speculated that the degree of interaction with guests and level of professionalism and responsibility are major determinants of prestige and image.

It is clear that as an exploratory study, our paper lack theories and models to account for many of our findings, and limits our ability to form solid contextualization. Hence, a considerable amount of the findings is presented here, to be the basis for further inquiry. For example, it is interesting to note that in the current study, receptionists, security guards, maintenance crews, and room attendants received higher recognition from the sub-sample of line level employees in the hospitality industry than from the sub-sample of the general public. It is speculated that hotel employees have a better appreciation than the general public does, as they are aware of the efforts, talents, skills, contribution, and responsibility involved in each one of these jobs. Hence, they possibly indicate a better image due to their awareness of line-level employees' contribution to the overall guests' experience as well as their future behaviours (e.g., intention to revisit the hotel). The different levels of recognition might be viewed as a corroboration of the aforementioned assumption on a possible gap between the two segments of the study. 
As for the study's context, it should be mentioned that almost no reference was made to the presence of migrant employees or the flourishing hi-tech industry. The fact that these two socio-economic trends were hardy mentioned (not even in the exploratory stage) should be further clarified. This point cannot be over-emphasized, as it served as one of the main impetuses for the current study.

\section{Conclusions}

Unlike the recurring themes of hard work, low pay, and low prestige, our study reveals a multifaceted image that comprises of eight factors. While these factors may include the aforementioned negative issues that have been long discussed in the literature, the model developed here allows for the consideration of other factors such as professional training and pride in ones' work. Furthermore, the DA enabled us to extract the employment images profiles of the public vs. the hospitality employees. Unravelling the core dimensions of the image of hospitality employment adds a layer to our understanding of employees' behaviour, and contributes to the investigation of employment images within a particular context.

The current exploratory study also revealed that the image of six line-level occupations selected for the study are perceived differently between and within samples. In sum, this study clearly demonstrates that the image of line-level employment and occupations in hospitality is more complex and challenging than could be presumed from the literature and there is a definite gap between employees and public perceptions. As noted earlier, these exploratory observations may serve as a steppingstone for further studies that will shed light on the image of hospitality industry employment, in light of other industries image and the general public's perceptions.

\section{Managerial Implications}

The study's results are highly applicable to hotels, at least in the country where the data was collected, Israel. The employees' occupational images and their tendency to be more positive than the publics' make them natural partners of the hotel management recruitment efforts. Specifically, hotel line-level employees can provide a reliable information relevant to the image of their current occupation. Moreover, given the relatively higher values assigned by current hospitality employees to various linelevel occupations, it is recommended to involve them into the recruitment process, as testimonials. A direct contact of candidates with current employees can be a rewarding experience for both sides. It empowers the employees, and at the same time reliable information is passed on to the inquiring candidates. Cooperation with employees can also take place in media campaigns for recruitment, where testimonials are also given by satisfied employees. It is recommended in such campaigns to set in the front and highlight occupations whose image is higher than others.

On another level, regional or national hotel associations can embark on sectorial promotional campaigns aimed at line-level employees, elaborating on the advantages of employment in the hotel industry in terms of employee protection laws, job security, health insurance, and family atmosphere. Given the weak impact of the hi-tech industry and the flow of illegal migrant employees, recruitment can be carried out in a non-apologetic fashion, aiming at those whose current working conditions as well as benefits are desirable. The hospitality employees who participated in the current study do not assign much significance to the role of hi-tech and migrant employees in the formation of the image of their employment. They seem to be insulated from these external trends, and therefore the focus on recruitment and retirement might be on industry and hotel specific attributes, and not factors that attempt to compensate for the lack of hi-tech conditions and for the possible impact of the low image of migrant workers. 
Given the findings about prestige assigned to employment in hotels catering to international tourists as noted in Reichel et al. (2014), it is recommended that, if possible, ratio of international tourists be increased in hotels. This might raise the image of line-level employment and affect reticent "Generation Y" hospitality program graduates (Barron, 2008; Solnet \& Hood, 2008).

Although it seems simplistic and naïve to claim that raising the salary would have an immediate impact on line-level employment image, hotel management should consider it. The globally mentioned "low wage" of the hospitality industry can confront an option of increasing employees' income as a possible means of attracting and retaining a sustainable higher-quality compact core of employees. Moreover, providing for such a cadre a clear career path might increase loyalty to the organization and industry. Thus, it may be possible to gradually create a sustainable workforce with a "positive spirit" that will upgrade both the industry and the public's image of hospitality employment. This "positive attitude workforce" resonates with the ideas of Pizam and Shani (2009) and Kuslavan, Kuslavan, Ilhan, and Byruk (2010), who suggested recruiting "suitable employees/students" who identify deeply with the industry and its conditions. Managing this cadre could require the cooperation of managers who empower their subordinates, sharing knowledge, information, and power. (Huertas-Valdivia, LlorensMontes, and Ruiz-Moreno, 2017). One of the literature's main conclusions is that a major change in hotel management culture and practice is needed. This can begin by relating to the "required sacrifices" (Factor Four). Apart from the wage issue, care for employee's family and personal life. Such possible policies are in line with McGinley and Wei's (2018) recommendation on alleviating emotional labour.

In sum, it is suggested to develop a sustainable cadre of highly motivated line-level workforce, appropriately rewarded, who will be relatively "immune" or "resilient" to the future external social pressures of hi-tech vs. migrant employment images, enjoy emotional labour, and derive job satisfaction, ready to work toward improving the hospitality work environment image.

\section{Limitations and Future Studies}

The generalization of the findings is limited due to the focus on a single country, Israel. Israel's unique hotel workforce characteristics and culture may raise several issues. For example, special incentives are offered to honorary discharged soldiers (after a three-year mandatory service) to entice them to join the hotel industry. Additionally, due its geo-political situation, Israel's hospitality industry is considered "unstable" in its demand fluctuations (Mansfeld, 1999). Given the scope of the current study, no conclusions can be drawn about a possible link between a specific line-level job image and a hotel type. For example, it may be that the image of a waiter in a business hotel is perceived as having higher status than a waiter in a resort. Clearly, these limitations call for additional studies focusing on how images are formed and nurtured. Finally, future studies should attempt to improve the measurement of factors related to the image of line-level employment in the hospitality industry. Such studies could contribute to the literature focusing on human resource management in hospitality.

\section{References}

Bahar, Y. (2017). An interview on hotel R \& F employees' age distribution. Israel Hotel Association, Tel Aviv, July 23, (in Hebrew).

Bahar, Y. (2019). An overview of the hospitality industry in Israel”. Israel Hotel Association, Be'er-Sheva, December, 19, (in Hebrew)

Baron J. N. (1984). Organizational perspectives on stratification. Annual Review of Sociology, 10, 37-69.

Barron, P. (2008). Education and talent management: implications for the hospitality industry. International Journal of Contemporary Hospitality Management, 20 (7), 730-742. 
Baum, T. (1995). Managing Human Resources in the European Tourism and Hospitality Industry: A Strategic Approach. London: Chapman \& Hall.

Baum, T. (1996). Unskilled work and the hospitality industry: myth or reality? International Journal of Hospitality Management, 15 (3), 207-210.

Baum, T. (2002). Skills and training for the hospitality sector: a review of issues. Journal of Vocational Education and Training, 54 (3), 343-364.

Baum, T. (2007). Human resources in tourism: Still waiting for change. Tourism Management, 28, 13831399.

Baum, T. (2018). Sustainable human resource management as a driver in tourism policy and planning: a serious sin of omission? Journal of Sustainable Tourism, 26 (6), 873-889.

Baum, T., Amoah, V., \& Spivack, S. (1997). Policy dimensions of human resource management in the tourism and hospitality industries. International Journal of Contemporary Hospitality Management, 9 (5/6), 221-229.

Boullé M., \& Reithler C. (200o). France: Maintaining French Identity in the Face of Globalization. In Hofmann S.M., Johnson C., \& Lefever M.M. (Ed), International human resource management in the hospitality industry (pp.43-64). Michigan, Educational Institute of the American Hotel and Motel Association, Lansing.

Brown, E. A., Thomas, N.J., \& Bosselman, R. H. (2015). Are they leaving or staying: A qualitative analysis of turnover issues for Generation Y hospitality employees with a hospitality education. International Journal of Hospitality Management, 46, 130-137.

Browne P., \& Golembiewski, R., T. (1974). The line-staff concept revisited: An empirical study of organizational images. Academy of Management, 17 (3), 406-417.

Cheng, T.Y., \& Tung, V.W.S. (2019). Dropping out of the hospitality industry after frontline work experience: an investigation into the personal changes of hospitality employees. International Journal of Hospitality \& Tourism Administration, DOI: 10.108o/15256480.2019.1598911

Choi, J., Woods, R. H., \& Murrmann, S. K. (200o). International labor markets and the migration of labor forces as an alternative solution for labor shortages in the hospitality industry. International Journal of Contemporary Hospitality Management, 12 (1), 61-66.

Cohen, N. Z. (2018). A panacea to human resource problem. URL: https://www.davar1.co.il/142081/rhu retrieved on 14, June 2020 (Hebrew).

Connolly, M. (2000). Human resource management in the Ireland: Industry's challenge during a period of unprecedented growth. In Hoffman, S.M., Johnson, C., \& Lefever, M.M. (Ed.), International hospitality human resource management (pp. 85-93). New-York, American Hotel \& Motel Association Publishing Co.

De Kadt, E. (1984). Tourism: Passport to development. Oxford: Oxford University Press.

Dutton, J. E., \& Dukerich, J.M. (1991). Keeping an eye on the mirror: Image and identity in organizational adaptation. Academy of Management Journal, 34 (3), 517-554.

Faulkenberry, L., Coggeshall, J., Backman, K., \& Backman, S. (2000). A culture of servitude: The impact of tourism development on South Carolina's Coast. Human Organization, 59, 86-95.

Filimonau, V., \& Mika, M. (2012). Return labour migration: an exploratory study of Polish migrant workers from the UK hospitality industry. Current Issues in Tourism, 22 (3), 357-378.

French, S. (2018). Between globalisation and Brexit: Migration, pay and the road to modern slavery in the UK hospitality industry. Research in Hospitality Management, 8 (1), 23-31.

Ganem, M. (2017). Personal Communication. Head of the Strategic Unit, Israel Ministry of Tourism. Jerusalem (in Hebrew).

Go, E., \& Lee, C. (2018). A workforce to be reckoned with: The emerging pivotal Generation Z hospitality workforce. International Journal of Hospitality Management, 73, 20-28. 
Gilbert, D., Guerrier, Y., \& Guy, J. (1998). Sexual harassment issues in the hospitality industry. International Journal of Contemporary Hospitality Management, 10 (2), 48-53.

Gioia, D. A., Schultz, M., \& Corley, K. G. (200o). Organizational identity, image, and adaptive instability. The Academy of Management Review, 25 (1), 63-81.

Guerrier, Y., \& Adib, A. (200o). 'No, we don't provide that service': The harassment of hotel employees by customers. Work, Employment E Society, 14 (4), 689-705.

Harpaz, I., \& Meshoulam, I. (1997). Intraorganizational power in high technology organizations. The Journal of High Technology Management, 8 (1), 107-128.

Hoffman, S.M., Johnson, C., \& Lefever, M.M. (2000). International Hospitality Human Resource Management. New-York: American Hotel \& Motel Association Publishing Co.

Hsieh, Y-C., Apostolopoulos, Hatzudis, K., \& Sönmez, S. (2014). Occupational exposures and health outcomes among Latina hotel cleaners. Hispanic Health Care International, 12 (1), 6-14.

Huertas-Valdivia, I., Llorens-Montes, F. J., \& Ruiz-Moreno, A. (2017). Achieving engagement among hospitality employees: A serial mediation model. International Journal of Contemporary Hospitality Management, 30 (1), 217-241.

Iacobucci, D., \& Churchill, G.A. (2010). Marketing Research: Methodological Foundations. 1oth Edition, Canada: South-Western, Cengage Learning.

International Labor Organization. (2010). Developments and challenges in the hospitality and tourism sector. Issues paper for discussion at the Global Dialogue Forum for the Hotels, Catering, and Tourism Sector. Geneva, (23-24 November).

Janta, H., Brown, L., Lugosi, P., \& Ladkin, A. (2011). Migrant relationships and tourism employment. Annals of Tourism Research, 38 (4), 1322-1343.

Janta, H., Ladkin, A., Brown, L., \& Lugosi, P. (2011). Employment experiences of Polish migrant workers in the UK hospitality sector. Tourism Management, 32 (5), 1006-1019.

Joppe, M. (2012). Migrant workers: Challenges and opportunities in addressing tourism labor shortages. Tourism Management, 33, 662-671.

Jung, H. S., \& Yoon, H. H. (2016). What does work meaning to hospitality employees? The effects of meaningful work on employees' organizational commitment: The mediating role of job engagement. International Journal of Hospitality Management, 53, 59-68.

Karatepe, O.M., \& Karatepe, T. (2009). Role stress, emotional exhaustion, and turnover intentions: Does organizational tenure in hotels matter? Journal of Human Resources in Hospitality $\mathcal{E}$ Tourism, 9 (1), 1-16.

Kattara, H. S. (200o). Egypt: An attempt to improve human resources practices. In Hoffman, S.M., Johnson, C., \& Lefever, M.M. (Ed.), International Hospitality Human Resource Management (pp.2740). New-York, American Hotel \& Motel Association Publishing Co.

Kensbock, S., Bailey,J., Jennings, G., \& Patiar, A. (2015). Sexual harassment of women working as room attendants within 5-Star hotels. Gender, Work and Organization, 22 (1), 36-50.

Kim, K., \& Jogaratnam, G. (2010). Effects of individual and organizational factors on job satisfaction and intent to stay in the hotel and restaurant industry. Journal of Human Resources in Hospitality $\mathcal{E}$ Tourism, 9 (3), 318-339.

Koc, E., \& Bozkurt, G.A. (2017). Hospitality employees' future expectations: Dissatisfaction, stress, and burnout. International Journal of Hospitality ETourism Administration, 18(4), 459-473, DOI: 10.1080/15256480.2017.1305318

Krakover, S. (2000). Partitioning seasonal employment in the hospitality industry. Tourism Management, 21, 461- 471.

Kuslavan, S., Kuslavan, Z., Ilhan, I., \& Byruk, L. (2010). The human dimension: A review of human resources management issues in the tourism and hospitality industry. Cornell Hospitality Quarterly, 51 (2), 171-214. 
Ladki, S. M., (200o). Human challenges facing the Lebanese hospitality industry. In Hoffman, S.M., Johnson, C., \& Lefever, M.M. (Ed.), International Hospitality Human Resource Management (pp. 173-180). New-York, American Hotel \& Motel Association Publishing Co.

Lindsay, C., \& McQuaid, R. W. (2004). Avoiding the 'McJobs': Unemployed job seekers and attitudes to service work. Work, Employment and Society, 18, 297-319.

Mansfeld, Y. (1999). Cycles of war, terror, and peace: Determinants and management of crisis and recovery of the Israeli tourism industry. Journal of Travel Research, 38 (1), 30-36.

McGinley, S., \& Wei, W. (2018). Emotional labor's impact on hoteliers outside the workplace. International Journal of Contemporary Hospitality Management, 30 (9), 2965-2983.

Momsen, J. (1994). Tourism, gender and development in the Caribbean". In Kinnaird, V., Kothari, U. \& Hall, D. (Ed.), Tourism: A gender analysis (pp. 106-118). Chichester: Wiley.

Newnham, M.P. (2017). A comparison of the enactment and consequences of emotional labor between frontline hotel workers in two contrasting societal cultures. Journal of Human Resources in Hospitality \& Tourism, 16 (2), 192-214.

Patton, M. E. (200o). The republic of Korea: Human resource management in a Confucian society. In Hoffman, S.M., Johnson, C., \& Lefever, M.M. (Ed.), International Hospitality Human Resource Management (pp.145-170). New-York, American Hotel \& Motel Association Publishing Co.

Pattullo, P. (1996). Last resorts: The cost of tourism in the Caribbean. London: Cassell.

Pearlman, D.M., \& Schaffer, J.D. (2013). Labor issues within the hospitality and tourism Industry: A study of Louisiana's attempted solutions. Journal of Human Resources in Hospitality E Tourism, 12 (3), 217-242.

Pfeffer J. (1977). Toward an examination of stratification in organizations. Administrative Science Quarterly, 22, 553-567.

Pizam, A. (1982). Tourism manpower: The state of the art. Journal of Travel Research, 21 (2), 5-9.

Pizam, A. (2003). Editorial: "Goodbye Rodney Dangerfield". International Journal of Hospitality Management, 22 (3), 241-242.

Pizam, A., \& Shani, A. (2009). The Nature of the Hospitality Industry: Present and Future Managers' Perspectives. Anatolia, 20 (1), 134-150.

Population and Immigration Authority (2018). Data on foreigners in Israel. URL: https://www.gov.il/BlobFolder/generalpage/foreign_workers_stats/he/foreigners_in_Israel_data _2017.pdf (in Hebrew, retrieved on 27, August 2019).

Ram, Y. (2018). Hostility or hospitality? A review on violence, bullying and sexual harassment in the tourism and hospitality industry. Current Issues in Tourism, 21 (7), 760-774.

Reichel, A., \& Amit, S. (200o). Human resource management in the Israeli hospitality industry.In Hoffman, S.M., Johnson, C., \& Lefever, M.M. (Ed.), International Hospitality Human Resource Management (pp. 95-111). New-York, American Hotel \& Motel Association Publishing Co..

Reichel, A. Fuchs, G., Pizam, A., \& Poria, Y. (2014). Occupational self- perceptions of hotel employees: An exploratory study. Tourism Analysis: An Interdisciplinary Journal, 19 (5), 545-658.

Reichel, A., \& Pizam, A. (1984). Job satisfaction, lifestyle and demographics of US hospitality industry workers-versus others. International Journal of Hospitality Management, 3 (3), 123-133.

Richardson, S. (2009). Undergraduates' perceptions of tourism and hospitality as a career choice. International Journal of Hospitality Management, 28, 382-388.

Riley, M. (1996). Human Resource Management in the Hospitality and Tourism Industry, 2nd ed. Oxford: Butterworth-Heinemann.

Robinson, R. N.S. (2008). Revisiting hospitality's marginal worker thesis: A mono-occupational perspective. International Journal of Hospitality Management, 27(3), 403-413.

Rosenberg, D. (2018). Israel as a Knowledge Economy II. In Israel's Technology Economy. Middle East in Focus (pp. 57-79). Cham, Palgrave Macmillan. 
Rowley, G., Purcell, K., Richardson, M., Shackleton, R., Howe, S., \& Whiteley, P. (200o). Employers skill survey: Case study of the hospitality industry. Nottingham: DFEE.

Shachmurove, Y. (2019). Determinants of economic growth in Israel. In Osińska M. (eds) Economic Miracles in the European Economies (pp. 99-121). Cham: Springer.

Senor, D., \& Singer, S. (2011). Start-up Nation: The Story of Israel's Economic Miracle. New York: Hachette Books Group.

Shamima, S., Cang, S., \& Yu, H. (2017). Supervisory orientation, employee goal orientation, and knowledge management among front line hotel employees. International Journal of Hospitality Management, 62, 21-32.

Shani, A., Uriely, N., Reichel, A., \& Ginsburg, L. (2014). Emotional labor in the hospitality industry: The influence of contextual factors. International Journal of Hospitality Management, 37, 150-158.

Singh, N., Hu, C., \& Roehl, W. S. (2007). Text mining a decade of progress in hospitality human resource management research: Identifying emerging thematic development. Hospitality Management, 26, 131-147.

Skoulas, N.V. (200o). Greece: the hospitality industry in transition. In Hoffman, S.M., Johnson, C., \& Lefever, M.M. (Ed.), International Hospitality Human Resource Management (pp. 67-82). New York, American Hotel \& Motel Association Publishing Co.

Solnet, D., \& Hood, A. (2008). Generation Y as hospitality employees: Framing a research agenda. Journal of Hospitality and Tourism Management, 15 (1), 59-68.

Szivas, E. (1999). The influences of human resources on tourism marketing. In Vellas, F., \& Becherel, L. (Ed.), The international marketing of travel and tourism: A strategic approach, (pp. 145-155). London, Macmillan.

Szivas, E., Riley, M., \& Airey, D. (2003). Labor mobility into tourism: Attraction and Satisfaction. Annals of Tourism Research, 30 (1), 64-7.

Vigoda, E., \& Ben-Zion, E. (2003). The association between organizational image and the tendency to leave the military for high-tech industry. Megamot, 43, 460-488 (in Hebrew).

Walmsley, A. (2004). Assessing staff turnover: A view from the English Riviera. International Journal of Tourism Research, 6 (4), 275-287.

Wood, R.C. (1997). Working in Hotels and Catering. London: International Thomson Business Press.

Yagil, D. (2008). When the customer is wrong: A review of research on aggression and sexual harassment in service encounters. Aggression and Violent Behavior, 13 (2), 141-152.

Yam, L., Raybould, M., \& Gordon, R. (2018). Employment stability and retention in the hospitality industry: Exploring the role of job embeddedness. Journal of Human Resources in Hospitality $\mathcal{E}$ Tourism, 17 (4), 445-464.

Zopiatis. A, Constanti, P., \& Theocharous, A. L. (2014). Migrant labor in hospitality: The Cyprus experience. International Journal of Hospitality Management, 37, 111- 120.

Received: 12/04/2020

Accepted: 27/07/2020

Coordinating editor: Stanislav Ivanov 